\title{
Total Diz Protezi Uygulanan Hastalarda Postoperatif Ăgrı Yönetiminin İncelenmesi
}

Investigation of Postoperative Pain Management in Patients Who Underwent Total Knee Prothesis

\section{Şaziye ÖZGÜR ${ }^{1}$ Selda RIZALAR ${ }^{2}$}

\section{ÖZ}

Araştırma diz protezi cerrahisinde postoperatif ağrı düzeyi, ağrıya etki eden etmenler ve ağrı yönetiminden memnuniyet durumunu incelemek amaciyla yapılan tanımlayıcı bir çalışmadır. Araştırma evreni, OcakAralık 2016 tarihleri arasında diz protezi uygulanan tüm bireylerden, örneklem grubu ise araştırma kriterlerini karşılayan 60 kişiden oluşmuştur. Veriler Bireysel Özellikler Formu, Kısa Ağrı Envanteri (KAE) ve Görsel Kıyaslama Ölçeği (GKÖ) ile toplandı. Veri değerlendirmesi; yüzdelik, ortalama, KolmogorovSmirnov, Mann Whitney U testi ve Kruskal Wallis testi ile yapıldı. Araştırmaya katılanlarn \%75'i 50-70 yaş aralığında olup \%81'inin kadın olduğu saptandı. Hastaların en kötü yüksek ağrı puan ortalaması $5,32 \pm 1,21$, en düşük ağrı puanı $1,85 \pm 1,28$, ortalama ağr1 puanı $3,35 \pm 0,91$, ölçüm anındaki ağrı puan ortalaması 1,62 $\pm 1,10$ bulundu. Her gün analjezik kullanımı olan kişilerin ağrı düzeyinin, kullanmayanlardan yüksek olduğu belirlendi. Analjezik yapıldıktan sonra hastaların ağrısının geçme oranlar1; \%36,7'sinde tamamen, \%18,3'ünde ise $\% 90$ oranında olduğu belirlendi. Hastaların ağrı nedeniyle en çok yürüyebilme, duygusal durum ve genel hareketlilik açısından etkilendiği görüldü. Protezli hastaların ağrı yönetimi memnuniyet puan ortalaması 6,25 bulundu. Bireylerin en düşük ağrı puan ortalamaları ile memnuniyet puanları arasında istatistiksel olarak önemli ilişsi bulundu. En hafif ağrı puanı azaldıkça ağrı yönetiminden memnuniyetin arttı̆̆1 görüldü. Diğer bağımsız değişkenlerin memnuniyet puanını etkilemediği belirlendi.

Anahtar Kelimeler: Ağrı, Ağrı yönetimi, Hemşirelik, Total diz protezi

\begin{abstract}
The study is a descriptive study to investigate the postoperative pain level, the factors affecting the pain, and satisfaction with pain management in the knee prosthesis surgery.The research community comprised all the knee prothesis applied individuals between January and December, 2016, the sampling included of 60 patients who fulfilled the study criteria. Data were collected with the PersonalCharacrestics Form, Brief Pain Inventory (BPI) and Visual Analog Scale (VAS). Data evaluation was done with Percentage, mean, Kolmogorov-Smirnov,Mann Whitney $U$ test and Kruskal Wallis test. It was found that $75 \%$ of the patients were in the 50-70 age range and $81 \%$ were women. The most severe pain score average of the patients was $5.32 \pm 1.21$, the mildest pain score is $1.85 \pm 1.28$, mean pain score average $3.35 \pm 0.91$, the mean pain score during the measurement was $1.62 \pm 1.1$. It was determined that the patients who use analgesics daily in their daily lives have higher pain levels than those who do not. After analgesic administration, $36.7 \%$ of patients recovered completely from pain, and $18.3 \%$ of patients recovered from $90 \%$. It was viewed that the patients were most affected by walking, emotional status and general activity due to pain. The average satisfaction with pain management score of the patients was 6.25.A meaningful relationship was found between the mildest pain scores and satisfaction scores of the patients. It was determined that as the mildest pain score decreased, satisfaction with pain management increased. It was found that other independent variables did not affect the satisfaction score.
\end{abstract}

Keywords: Pain, Pain management, Nursing, Total knee prothesis.

Bu çalışma 3. Uluslararası 11. Ulusal Türk Cerrahi ve Ameliyathane Hemşireliği Kongresi 2019'da sözel bildiri olarak sunulmuştur.

${ }^{1}$ Uzman Hemşire, Şaziye ÖZGÜR, Arnavutköy Devlet Hastanesi, saziyeaksoy_@ hotmail.com ORCID: 0000-0002-2704-1035

2 Doç. Dr., Selda RIZALAR, Cerrahi Hastalıkları Hemşireliği, Sağlık Bilimleri Üniversitesi, Hamidiye Hemşirelik Fakültesi, selda.rizalar@sbu.edu.tr, ORCID: 0000- 0002-1592-9926 


\section{GIRISS}

Dünyada en yaygın görülen artrit formu olan osteoartrit genellikle toplumda ileri yaşlarda ortaya çıkan, eklem kıkırdağında dejenerasyon, osteofit oluşumu, subkondral skleroza neden olan hastalıktır. Epidemiyolojik çalışmalarda 65 yaş üzerindeki bireylerin \%10-30'unda semptom veren diz osteoartriti görüldüğü belirtilmektedir. Türkiye'de yapılan bir çalışmada ise 50 yaş üzerindeki kişilerde semptom veren diz osteoartriti prevalansının $\% 14,8$ olduğu, kadınlarda \%22,5, erkeklerde ise $\% 8$ olduğu bildirilmiştir. ${ }^{1}$

Diz osteoartriti, özellikle yaşı bireylerde diz ekleminin erozyonu sonucu ağrı ve hareket kısıtlılığına yol açmaktadır. Gelişen teknoloji ile birlikte hastalıkların tedavisinde cerrahi girişim uygulamalarının giderek arttı ğ 1 bilinmektedir. Diz osteoartritli hastalarda da ağrıya yönelik uygulanan tıbbi tedavi yöntemlerinin yanında cerrahi müdahale ile Total Diz Protezi (TDP) uygulaması sik uygulanan tedavi yöntemlerinden biridir. ${ }^{2}$ Total diz protezi ile amaçlanan, ağrının hafifletilmesi, deformitenin düzeltilmesi ve eklem fonksiyonunun arttırılmasıdır. Total diz protezi uygulaması ile temel olarak başarılı sonuçlar elde edilse de, yapılan araştırmalara göre hastalarda ameliyat sonrası ağrı yönetiminin kabul edilebilir düzeyde olmadığı görülmektedir. ${ }^{3}$ Postoperatif ağrı; cerrahi insizyon ile başlayıp, çoğu zaman kısa süren, yara iyileşmesi ilerledikçe günden güne azalan ve doku iyileşmesi ile son bulan akut bir ağrıdır. Ameliyat sırasında salınan kimyasal mediyatörlerin sinir hücrelerini uyarması, kas spazmı, basınç, ödem ve iskemi gibi nedenlere bağlı olarak hastalarda ameliyat sonrası ağr1 görülebilmektedir. ${ }^{3}$ Ortopedi hastalarında ameliyat sonrası ağrının incelendiği çalışmalarda, protez ameliyatı geçiren hastaların yüksek düzeyde ağrı deneyimledikleri belirtilmektedir. Akyol'un çalışmasında ortopedi hastalarının \%60'1 şiddetli, \%30'u ise orta düzeyde ağrı yaşadıklarını belirtmişlerdir.

Ameliyat sonrası ağrı, önceden tahmin edilen ve beklenen bir ağrı olduğundan aynı zamanda önlenebilir bir ağrıdır. Günümüzde ağrı giderilmesine yönelik bilgi ve teknolojik gelişmelerin artmasına karşın, hastaların çoğunda ameliyat sonrası ağrı kontrolü yetersiz kalabilmekte ve hastanede yatan pek çok hasta ağrı deneyimlemektedir. Literatürde ameliyat sonrası hastaların yaklaşık \%5070'inde ağrı tedavisinin yetersiz kaldığı, çeşitli nedenlerle orta veya şiddetli düzeyde ağrı yakınmaları olduğu bildirilmiştir. ${ }^{4-8}$

Araştırmalar ağrının çok boyutlu olarak değerlendirilmesi ve etkili ağrı yönetimi uygulamalarının geliştirilmesini önermektedir. Ağrı yönetimine doğru karar verebilmek için ağrı değerlendirmesinin doğru yapılması gerekir. ${ }^{3}$ Amerikan Ağrı Derneği, ağrının önemine dikkat çekmek ve sağlık profesyonelleri arasındaki farkındalığı arttırmak amacıyla ağrıyı beşinci yaşamsal bulgu olarak nitelendirmiş ve ağrının da rutin şekilde değerlendirilerek kayıt altına alınnmasını amaçlamışlardır., ${ }^{3,9}$ Düzenli aralıklarla ağrının tanılanması ağrı yönetiminde önemlidir.

Total diz protezi ameliyatı sonrasında bireye günlük yaşam aktivitelerinde optimal düzeyde bağımsızlık kazandırmak, komplikasyonları önlemek ve hasta memnuniyetini sağlamak üzere ağrı yönetiminin etkin olarak sürdürülmesi önemlidir. ${ }^{3,10}$ TDP ameliyatı olmuş postoperatif dönemde şiddetli ağrı deneyimleyen hastaların bireyselleştirilmiş hemşirelik bakımı kapsamında ağrı tanılaması ve ağrı yönetimine ilişkin sınırlı sayıda çalışma bulunmaktadır. ${ }^{7,8}$ Diz artroplastisi uygulanan hastalarda ağrı düzeyi ve etkileyen faktörlerin araştırılması ile ağrı yönetiminde gerekli düzenlemelere gidilerek ağrının daha etkin şekilde giderilmesi sağlanabilecek ve hasta memnuniyetinin artırılması mümkün olacaktır. Çalışmanın amacı; total diz protezi girişimi yapılan hastalarda postoperatif dönemde ağrı seviyesinin, ağrıyı etkileyen faktörlerin ve ağrı yönetiminden memnuniyet durumunun belirlenmesidir. 


\section{MATERYAL VE METOT}

\section{Araştırmanın Tipi, Yeri ve Zamanı}

Araştırma, tanımlayıcı ve kesitsel olarak gerçekleştirildi. Araştırma; İstanbul ilinde bir Devlet Hastanesinin ortopedi servisinde Ocak -Aralık 2016 tarihleri arasında uygulanmıştır.

\section{Araștırmanın Evren ve Örneklemi}

Çalışmanın evrenini İstanbul ilinde bir devlet Hastanesi'nde TDP ameliyatı olan hastalar oluşturmuştur. Örneklem seçimi yapılmaksızın, hastanede çalışmanın yürütüldüğü süre içerisinde cerrahi girişim için kabul edilen tüm vakaların çalışmaya alınması planlandı. Ocak ve Aralık 2016 arasında TDP uygulanan hasta sayısinın 78 olduğu belirlendi. $\mathrm{Bu}$ vakalar içerisinde 15 hasta örneklem kriterlerini karşılamadığı için, üç hasta araştırmaya katılmayı kabul etmediği için çalışma dışı bırakıldı. Böylece araştırmanın örneklemi TDP ameliyatı olan 60 hastadan oluşmuştur. Çalışma örneklemine alınma kriterleri; 18 yaş ve üzerinde olmak, akut ağriya neden olacak başka bir sorunu bulunmamak, ameliyat sirasi ve sonrasinda komplikasyon gelişmemesi, çalışmaya katılmayı kabul etmektir. Çalışma dışında tutulma kriterleri; hepatik, renal ve kardiyovasküler hastalığı olması, ASA III, ileri derece riskli olması, ameliyat sonrası dönemde yoğun bakım ünitesinde izlem gerektirmesi, ameliyat sonrası dönemde enfeksiyon ya da derin ven trombozu gelişmesi, psikiyatrik ilaç kullanımı, kanama pıhtılaşma bozukluğu olmasıdır.

\section{Veri Toplama Araçları}

Çalışmanın verileri Katılımcı Bilgi Formu, KAE ve GKÖ ile topland. Katılımcı Bilgi Formu, hastanın yaşı, cinsiyeti, medeni durumu, eğitim durumu, boy, kilo, BKİ, mesleği, kronik hastalıkları, analjezik kullanımı, ameliyat sirasinda uygulanan anestezi yöntemi bilgilerini içermektedir. Kısa ağrı envanteri, toplam 9 sorudan oluşan bir formdur. İlk soru bireyin ağrısını geçmiş ağrı deneyimleriyle kıyaslar, ikinci soruda bireyin ağrı bölgesini işaretlediği bir görsel bölüm bulunur. Sonraki 4 soru ağrının şiddetini sayısal ağrı skalasında ölçmeye yöneliktir. Sayısal ağrı skalası 0-10 arasında değerlendirilir; ", '0", ağrısızlı̆̆1, ", '10"," dayanılmaz ağrıyı ifade eder. Ağrının şiddetine ait ölçümler, son bir gün (24 saat) içindeki en kötü, en hafif, ortalama ve görüşme sırasındaki ağrıyı göstermektedir. Formda ayrıca bireyin ağrıya yönelik aldığı ilaçlar ve ağrıdan kurtulma yüzdesi belirtilir. Son soru, bireyin son bir gün içindeki ağrıya bağlı; genel hareketlilik, duygusal durum, solunum ve öksürme egzersizi, kişilerarası ilişkiler, yürüme, uyku, çalışma ve yaşamdan zevk almanın etkilenme seviyesini ölçmektedir. Her bir madde 0'dan 10'a kadar sayısal ölçekte değerlendirilir; "', 0 ",' hiç etkilenmediğini, "', 100 "," tamamen etkilendiğini ifade etmektedir. KAE'nin ülkemizde postoperatif hasta örnekleminde geçerlik ve güvenirliği yapılmış, Cronbach $\mathrm{Cr}$ Alpha kat sayısı 0.79 saptanmıştır. $^{11}$ Araştırmamızda cronbach Cronbach Alfa katsayısı 0,673 bulundu. Çalışmamızda hastaların ağrı yönetiminden memnuniyetini ölçmek için GKÖ kullanıldı. GKÖ’ nün hasta memnuniyeti ölçümü amacıyla kullanıldığı çalışmalar mevcuttur. $\mathrm{Bu}$ ölçek $10 \mathrm{~cm}$ uzunluğunda dikey ya da yatay özellikte olup, bir ucunda "hiç memnun değilim", diğer ucunda ise "çok memnunum" ifadeleri yer almaktadır. Çalışmamızda ölçeğin $0-10 \mathrm{~cm}$ arasında yatay formu kullanıldı. ${ }^{12,13}$

\section{Verilerin Toplanması}

Araştırma verileri Hasta Bilgi Formu, KAE ve GKÖ kullanılarak yaklaşık 10 dakika sürecek şekilde, yüz yüze görüşme yöntemi ile elde edilmiştir. Öncelikle hastalara sözlü olarak çalışmanın amacı hakkında bilgi verilerek izin alındı. KAE, son bir güne ilişkin ağrıyı ve hareketlilikteki engellenmeyi değerlendirdiği için, ameliyat sonrası ikinci güne ait verileri yansitmaktadır. Ameliyat sonrası ilk 48 saat hastanın en yoğun ağrılı dönemidir. Ancak ilk 24 saat içinde hasta anestezi etkisindedir ve genellikle 24 saat civarında mobilize olduklarından 24-48 saatleri arasındaki ağrı şiddetini değerlendirebilmek amacıyla ölçek ameliyat sonrası 48-72 saatlik süre içerisinde uygulanmıştır. 


\section{Verilerin Değerlendirilmesi}

Araştırmanın verileri, SPSS (IBM) 17.0 programında yüzdelik, ortalama, Kolmogorov-Smirnov testi, Mann Whitney U testi ve Kruskal Wallis testi aracılığı ile analiz edildi. İstatistiksel olarak $\mathrm{p}<0.05$ olan değerler anlamlı kabul edildi.

\section{Araştırmanın Etik Boyutu}

Araştırmaya başlamadan önce KAE'ni Türkçe'ye uyarlayan yazarların izni alındı.
İstanbul Medipol Üniversitesi, Girişimsel Olmayan Araştırmalar Etik Kurulu'ndan 18.11.2015 / 541 Tarih ve No'lu etik kurul izni, İstanbul ili, Fatih Kamu Hastaneleri Birliği Genel Sekreterliği'nden kurum izni (21.12.2015 / E.27295) alınd1. Kat1lımc1ların gönüllülük esasına dayanarak sözlü ve yazılı onamları alındı.

\section{BULGULAR VE TARTIŞMA}

Çalışmaya alınan hastaların yaş ortalamasının $62,5 \pm 7,37$ olduğu, $\% 46,7$ 'sinin 60-69 yaş arasında, \%28,3'ünün 50-59 yaş arasında olduğu görüldü. Hastaların tamamının evli ve sağlık güvencesine sahip olduğu, \%81,7'sinin kadın olduğu, \%50'sinin 6-10 yıldır OA hastalığı olduğu görüldü. Hastaların \%83,3'ünün diyabet ve hipertansiyonu olduğu görüldü. Hastaların $\% 45$ 'inin haftada 1-2 kez, \%38,3'ünün her gün analjezik kullandığ 1 belirlendi. BKI incelendiğinde, hastaların \% 78,3'ünün obez, $\% 21,7$ 'sinin fazla kilolu olduğu belirlendi. Yanıtlar incelendiğinde ayrıca hastaların $\% 26,7$ 'sine genel anestezi, \%31,7'sine spinal anestezi, \%41,7'sine ise kombine anestezi yöntemi (spinal ve epidural) uygulandığ1 görüldü. Ağrı gidermek amaciyla hastalarda en çok kullanılan analjezikler; nonsteroid antienflamatuar analjezikler, opioidler, parasetamol ve lokal anestezikler olarak belirlendi. Ağrının başlamasından ağrı kesici yapılıncaya kadar geçen süre hastaların ifadesine göre \%33,3'ünde yarım saat, $\% 46,7$ 'sinde bir saat, \%20'sinde ise iki saat olarak belirtilmiştir (Tablo 1).

Tablo 1. Hastaların Tanıtıcı Özellikleri $(\mathrm{N}=60)$

\begin{tabular}{lrr}
\hline Değişkenler & Sayı & \% \\
\hline Yaş Grupları & & \\
\hline $40-49$ & 3 & 5,0 \\
$50-59$ & 17 & 28,3 \\
$60-69$ & 29 & 46,7 \\
$70+$ & 12 & 20 \\
\hline Cinsiyet & & \\
\hline Erkek & 11 & 18,3 \\
Kadın & 49 & 81,7 \\
\hline
\end{tabular}

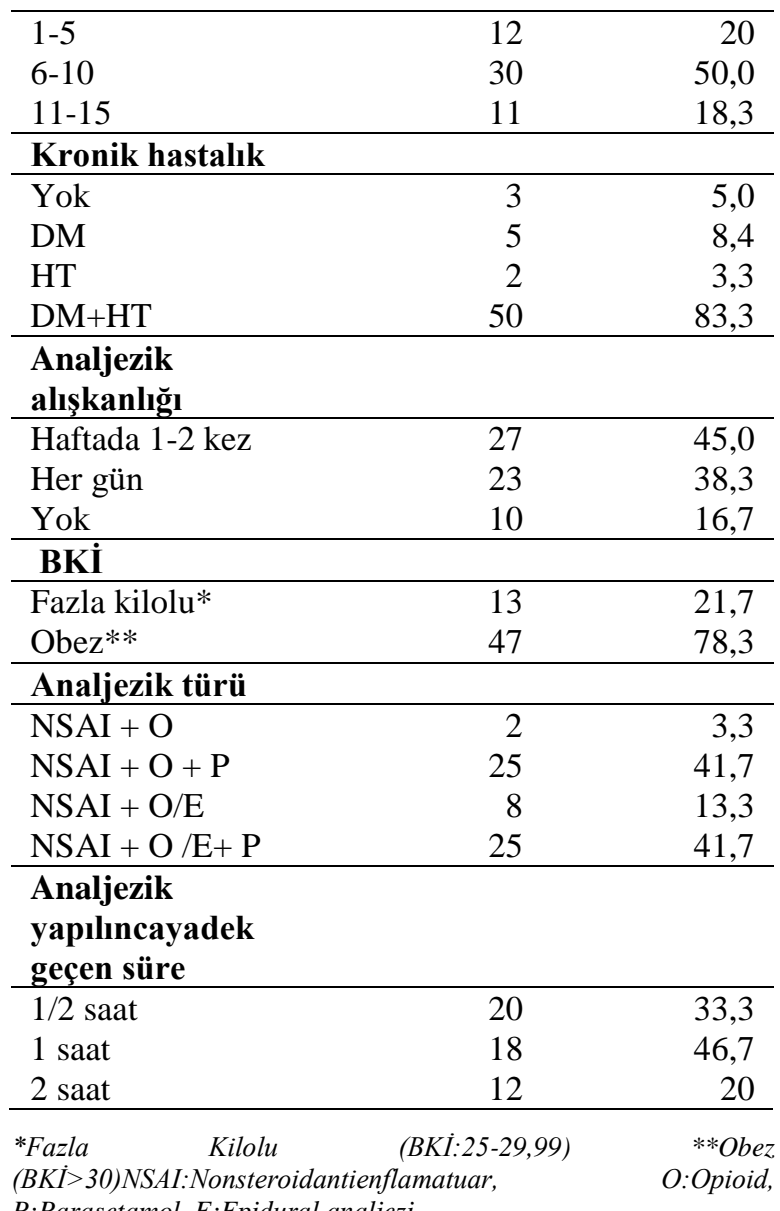

P:Parasetamol, E:Epidural analjezi

Çalışmamızda hastaların ameliyat sonrası ikinci güne ait en kötü ağrı puanı 5,32 $\pm 1,21$, en hafif ağrı puanı $1,85 \pm 1,28$, ortalama ağr1 puanı 3,35 $\pm 0,91$, ölçüm sırasındaki ağrı puanı $1,62 \pm 1,10$ olduğu görüldü (Tablo 2). Turhan Damar ve Bilik'ın çalışmasında en kötü ağrı puan ortalamasının $8,17 \pm 2,45$, en hafif ağrı puanının $3,16 \pm 2,18$ olduğu belirlenmiştir. ${ }^{14}$ İlgen ve ark. (2006)'nın yaptıkları bir çalışmada, en şiddetli ağrı puanının 6 , en hafif ağrı puanının ise 2'nin altında saptandığ1 
görülmektedir. ${ }^{15}$ Akyol (2008)'in yaptığ1 çalışmada hastaların deneyimledikleri en şiddetli ağrı puanı 7.20, en hafif ağrı puanı 2.38; ortalama ağrı puanı 3.70 olarak saptanmıştır. ${ }^{3}$ Ağrı değerlendirmesinin 100 puan üzerinden yapıldığ 1 bir çalışmada ise hastaların en şiddetli ağrı puanı 47,8 , ortalama ağr1 puanı ise 33,1 olarak bulunmuştur. ${ }^{16}$ Çalışmamızdaki ortopedik cerrahi hastalarının ağrı puan ortalamalarının literatür ile uyumlu olduğu söylenebilir.

Çalışmamızda hastaların ağrı nedeniyle günlük yaşamındaki engellenme puanı 10 üzerinden hesaplandığında ilk sırada yürüme aktivitesinin engellendiği $(3,22 \pm 1,93)$ yer almıştır. Genel aktivite yönünden engellenme puanı 2,83 $\pm 2,62$, emosyonel yönden etkilenme puanı $2,83 \pm 3,12$, uyku etkilenme puanı $1,95 \pm 2,44$, yaşamdan zevk alma etkilenme puanı 1,35 $\pm 1,21$ derin solunum ve öksürme etkilenme puanı $0,25 \pm 1,08$, insanlarla ilişkilerin etkilenme puanı 0,25 $\pm 0,00$ olduğu belirlendi (Tablo 2).

Çalışmamızda ameliyat sonrası yaşanan ağrı nedeniyle diz protezi uygulanan hastaların yürüme ve genel aktivite düzeylerinin olumsuz etkilendiği belirlenmiştir. Turhan Damar'ın çalışmasında da en çok engellenmenin yürüme ve genel aktivitelerde yaşadıkları belitilmektedir. ${ }^{14}$ Hastalar ağrıya bağlı günlük yaşam aktivitelerinde hareket kisitlılığ1 yaşamaktadırlar. Ameliyat sonrası ağrının yüksek olması hastaların günlük yaşam aktivitelerini kısıtlamaya, ROM egzersizlerini yapmamaya ve fiziksel performansta azalmaya neden olmaktadır. Hastalar ağrı yaşadıkları için mobilizasyonu daha geç gerçekleşmektedir. $\mathrm{Bu}$ nedenle etkin ağrı yönetimi ile erken mobilizasyon ve ameliyat sonrası oluşabilecek komplikasyonların engellenmesi sağlanabilir. Bulgularımıza bakıldığında dikkati çeken bir önemli nokta da aktivite engellenme puanı ile emosyonel etkilenme puanının eșit olmasıdır. Hastaların ameliyat sonrasinda fiziksel engellenme oranında duygusal engellenme yaşadıkları görülmektedir.

Tablo 2. Hastaların KAE'ne Göre Son 24 Saatteki Ağrı Şiddeti ve Engellenme Puanları

\begin{tabular}{lrr}
\hline & $\mathrm{X} \pm \mathrm{SS}$ & min-mak \\
\hline Son 24 saatteki ağrı şiddeti & & $2-9$ \\
\hline Son 24 saatteki en kötü ağrı & $5,32 \pm 1,21$ & $0-4$ \\
Son 24 saatteki en hafif ağrı & $1,85 \pm 1,28$ & $1-5$ \\
Son 24 saatteki ort ağrı & $3,35 \pm 0,91$ & $0-4$ \\
Şu anki ağrı & $1,62 \pm 1,10$ & \\
\hline Son 24 saatte aktivitelerdeki & & $0-9$ \\
engellenme & & $0-10$ \\
\hline Genel aktivite & $2,83 \pm 2,62$ & $0-10$ \\
Emosyonel durum & $2,83 \pm 3,12$ & $0-8$ \\
Yürüyebilme & $3,22 \pm 1,93$ & $0-2$ \\
Derin solunum ve öksürme & $0,25 \pm 1,08$ & $0-10$ \\
Diğer insanlarla ilişkiler & $0,25 \pm 0,50$ & $0-5$ \\
Uyuma & $1,95 \pm 2,44$ & $1,35 \pm 1,21$ \\
Yaşamdan zevk alma & & \\
\hline
\end{tabular}

Hastaların yaş grupları, kronik hastalık durumu, BKİ, kullanılan analjezik türü, uygulanan anestezi yöntemine göre ağrı puanları arasında anlamlı fark bulunmadi. En hafif ağrı ve görüşme esnasındaki ağrıya bakıldığında; 11-15 yıldır OA tanısı olan hastaların ağrısının diğer gruplara oranla yüksek olduğu görüldü. Hastaların yaş gruplarına göre ağrı puanları arasında anlamlı fark bulunmadi. Ülkemizde, Akyol (2008) 'in yaptığı çalışmada hastaların yaş gruplarına göre ağrı şiddetleri arasında istatistiksel yönden anlamlı fark bulunmamıştır. ${ }^{3}$ Uluslararası literatür incelendiğinde; Berges ve ark. (2006)'nun yaptıkları çalışmada da diz ve kalça protezi uygulanan hastaların yaşlarına göre ağrı şiddetleri arasında istatistiksel olarak anlamlı bir fark 
bulunmamıştır. ${ }^{17}$ Hastaların \%81,7'sinin kadın olduğu saptandı. Erkek hastaların görüşme anındaki ağrı puanı kadınlara oranla yüksek bulundu. Turhan Damar ve Bilik'in (2018) çalışmasında kadın ve erkek hastaların ağrı düzeyleri arasında fark bulunmamıştır. ${ }^{14}$ Berges ve ark'(2006)'nun TKP uygulanan hastalarla ilgili yaptıkları çalışmada ise cinsiyetlere göre ağrı puanları arasında fark bulunmamıştır. ${ }^{17}$ Literatür incelendiğinde Cremeans-Smith ve ark'(2006)'nun TDP uygulanan hastalarla yaptıkları çalışmada, kadın hastaların ağrı puanının erkek hastalardan daha yüksek olduğunu saptamışlardır. ${ }^{18}$ Akyol (2008)'in yaptığı çalışmada kadın hastaların ağrı puanı erkek hastalara göre yüksek saptanmıştır. ${ }^{3}$ Nikolajsen ve ark (2006)'nın TKP yapılan hastalarla yaptıkları çalışmada, kadın hastaların erkek hastalardan daha fazla ağrı şikâyetinde bulundukları saptanmıştır. ${ }^{19} \mathrm{Bu}$ bulgumuz literatür bilgisi ile uyumlu değildir. Kadınlarda ağrı eşiğinin düşük olduğu bilgisine s1k rastlanmaktadır.

Hastaların \%83,3'ünün DM yada HT hastalığının olduğu görüldü. Kronik hastalık varlığının ağrı düzeyi üzerinde etkisi olmadığı belirlendi. Benzer şekilde Akyol (2008)'in yaptı̆̆ 1 çalışmada kronik hastalık durumunun ağr1 puanını etkilemediği bulunmuştur. ${ }^{3}$ Karayurt (1998)'un yaptığı çalışmada da kronik hastalık varlığının ağrı puanlarını etkilemediği belirtilmiştir. Bulgularımızın literatür ile uyumlu olduğu söylenebilir. ${ }^{20}$

Çalışmada hastaların \%45'inin haftada 1-2 kez, \%38,3'ünün her gün analjezik kullandığ1 belirlendi. Her gün analjezik kullanma alışkanlığı olanların ağrı düzeyinin, olmayanlara oranla daha yüksek olduğu belirlendi. Analjezik kullanım alışkanlığına göre ağrı puanı ortalamaları incelendiğinde; en hafif ağrı, ortalama ağrı ve şu anki ağrı seçenekleri arasında istatistiksel olarak anlamlı fark bulundu $(p<0,05)$. Her gün düzenli analjezik kullananların ağrı düzeyinin, analjezik kullanmayan ve haftada birkaç kez kullananlara oranla yüksek olduğu belirlendi. Yıldırım (2013)'ın çalışmasında analjezik kullanım alışkanlığının ağrı şiddetini etkilemediği bildirilmiştir. ${ }^{2}$

Hastaların BKI'leri incelendiğinde, \%78,3'ünün obez, \%21,7'sinin fazla kilolu olduğu belirlendi. BKİ kategorilerine göre ağrı düzeyleri arasında fark olmadığı görüldü. Altındağ ve ark. (2006)'nın yaptığı çalışmada ise BKİ ile ağrı arasında pozitif yönde ve anlamlı bir korelasyon olduğu bildirilmiştir. ${ }^{21}$ Mutlu (2016)'nun aktardığına göre Ciccuttini ve arkadaşları tarafından yapılan çalışmada obezitenin diz osteoartiriti ile ilişkili olduğu ancak TDP uygulanan hastalarda ameliyat sonrası BKI'nin ağriya etkisini belirten çalışmaya rastlanmamıştır. ${ }^{22}$

Tablo 3. Hastaların Bireysel ve Tıbbi Özelliklerine Göre KAE Ağrı Puanlarının Dağılımı (n=60)

\begin{tabular}{|c|c|c|c|c|c|}
\hline \multirow[t]{3}{*}{ Özellikler } & & \multicolumn{3}{|c|}{ Son 24 saat } & \multirow[t]{2}{*}{ Şu anki ağrı } \\
\hline & & En kötü ağrı & En hafif ağrı & Ortalama ağrı & \\
\hline & & $\mathrm{X} \pm \mathrm{SS}$ & $\mathrm{X} \pm \mathrm{SS}$ & $\mathrm{X} \pm \mathrm{SS}$ & $\mathrm{X} \pm \mathrm{SS}$ \\
\hline \multicolumn{6}{|l|}{ Cinsiyet } \\
\hline Kadın & & $5,24 \pm 1,3$ & $2 \pm 1,323$ & $3,37 \pm 0,951$ & $1,41 \pm 0,956$ \\
\hline \multirow[t]{2}{*}{ Erkek } & & $5,64 \pm 0,674$ & $1,18 \pm 0,874$ & $3,27 \pm 0,786$ & $2,55 \pm 1,293$ \\
\hline & $M W U ; \boldsymbol{p}$ & $198 ; 0,15$ & 172,$5 ; 0,057$ & $255 ; 0,77$ & 142,$5 ; 0,012$ \\
\hline \multicolumn{6}{|c|}{ Yaş grupları } \\
\hline $40-49$ & & $5,33 \pm 1,155$ & $2,67 \pm 1,32$ & 3,00 & $1,33 \pm 1,155$ \\
\hline $50-59$ & & $5,35 \pm 1,32$ & $1,59 \pm 1,064$ & $3,29 \pm 0,849$ & $1,71 \pm 0,772$ \\
\hline $60-69$ & & $5,46 \pm 1,138$ & $2,07 \pm 1,464$ & $3,57 \pm 0,959$ & $1,68 \pm 1,307$ \\
\hline \multirow[t]{2}{*}{$70+$} & & $4,92 \pm 1,311$ & $1,5 \pm 1,168$ & $3 \pm 0,953$ & $1,42 \pm 1,084$ \\
\hline & $K W ; p$ & 0,$812 ; 0,847$ & 3,$564 ; 0,313$ & 3,$949 ; 0,267$ & 0,$870 ; 0,833$ \\
\hline \multicolumn{6}{|c|}{ Osteoartrit süresi } \\
\hline $1-5$ y1l & & $5,58 \pm 1,08$ & $1,92 \pm 1,16$ & $3,33 \pm 0,98$ & $0,75 \pm 0,86$ \\
\hline 6-10 y1l & & $5,23 \pm 1,47$ & $1,2 \pm 0,84$ & $3,23 \pm 1$ & $1,87 \pm 1,22$ \\
\hline \multirow[t]{2}{*}{$11-15$ y1l } & & $5 \pm 0,63$ & $3,27 \pm 1,27$ & $3,73 \pm 0,64$ & $1,91 \pm 0,7$ \\
\hline & $K W ; p$ & 4,$987 ; 0,173$ & 2,$466 ; 0,00$ & 3,$25 ; 0,355$ & 9,$826 ; 0,02$ \\
\hline
\end{tabular}


Tablo 3. (Devamı) Hastaların Bireysel ve Tıbbi Özelliklerine Göre KAE Ağrı Puanlarının Dağılımı

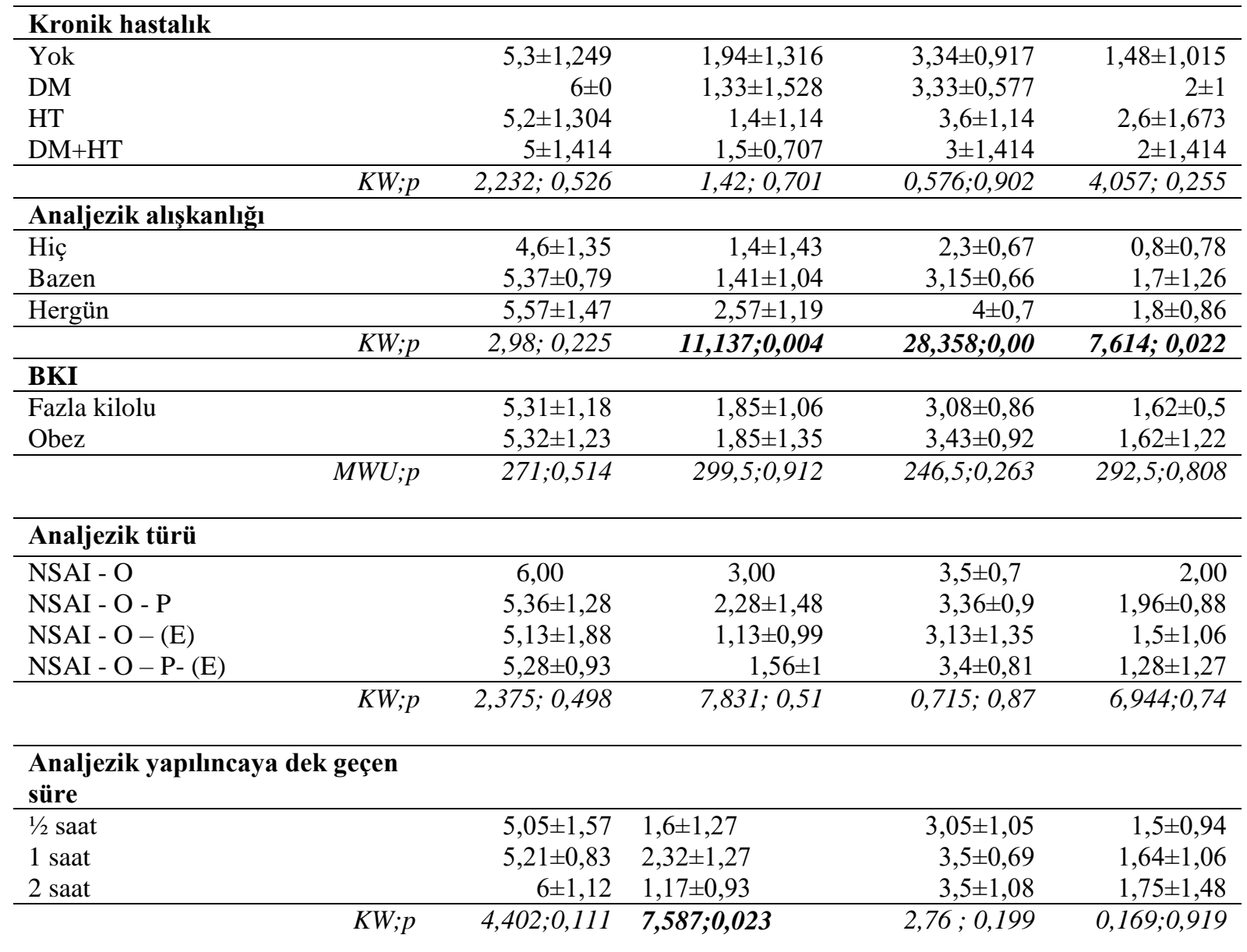

NSAI:Nonsteroid antienflamatuar O:Opioid P:Parasetamol E:Epidural analjezi

Farmakolojik tedavide narkotik ve narkotik olmayan analjezik ilaçlarla tama yakın bir ağrısızlık ve konfor sağlanacağı bilinmekle birlikte cerrahi hastaların büyük bir kısmının ağrı çekiyor olması ameliyat sonrası ağrı yönetiminin etkili olmadığını düşündürmektedir. Çalışmamızda, ameliyat sonrası dönemde NSAI ve opoid; NSAİ, opioid ve parasetamol; NSAİ, opioid ve epidural lokal anestezik; NSAİ, opioid, parasetamol ve epidural lokal anesteziklerden oluşan dört farklı analjezik grubu uygulandı. Çalışmamızda ameliyat sonrası kullanılan analjezik türünün ağrı düzeyini değiştirmediği bulunmuştur $\quad(p>0,05)$. Benzer şekilde Yıldırım (2013)'ın çalışmasında ameliyat sonrası verilen analjezik ile ağrı şiddeti arasında fark saptanmamıştır. ${ }^{2}$ Yaşlı hasta örnekleminde yapılan bir çalışmada protez uygulama ameliyatı sonrası ağrı yönetiminde hastaların \%95,3’üne NSAİ ilaçlar oral, intravenöz veya müsküler verilmiş olup, yalnızca \%4,7'sinde narkotik kullanıldığ 1 bildirilmiştir. ${ }^{14}$ Hastayı rahatsız eden ağrıyı gidermek ve iyileşmeyi hızlandırmak için genellikle nonopioid ilaçlar verilmektedir. DSÖ tarafından ağrı kontrolünde ilaç tedavisinin ilk basamağında ilk sırada NSAİ ilaçlar önerilmektedir. İlaca yanıt yetersiz olduğunda opioid türü ilaç ilavesi gerektiği belirtilmiştir. $^{23}$

Ancak ilacın verilmesine rağmen hastaların şiddetli ağriya sahip olması opioid ile desteklenmesi veya ilaç dışı yöntemler ile ağrı yönetiminin desteklenmesi gerektiğini göstermektedir. Yapılan çalışmalarda ülkemizde sağlık çalışanlarının opioid kullanmaktan kaçındığı bildirilmiştir. $^{23,24}$ Bunun nedenleri arasında bilgi yetersizliğinin yanı sıra hastayı ilaç yan etkilerinden koruma 
gereksinimi de yer almaktadır. Narkotik analjeziklerin solunum problemleri, hipotansiyon, bağımlılık gibi yan etkileri bulunmaktadır. ${ }^{14}$ Hekim ve hemşirelerin narkotik analjeziklerin bağımlılık yapma potansiyelinden endişe duydukları, düşük dozlarda ve uzun aralıklarda opioid verme eğiliminde oldukları belirtilmiştir, oysa DSÖ ağrı kontrolünde kombine tedaviyi önermektedir. ${ }^{23}$

Ağrı kontrolünde bazı önemli ilkeler vardır; analjezikler, etkili dozda kullanılmalı, gerektiğinde değil, saatinde uygulanmalı, analjezik dozu hastanın gereksinimlerine göre bireyselleştirilmeli, doz, ağnının şiddetine göre ayarlanmalı, hasta için en uygun veriliş yolu ayarlanmalıdır. ${ }^{2,3} \mathrm{Bu}$ çalışmada hastaların ifadesine göre ağrının başlamasından ağrı kesici yapılıncaya kadar geçen süre $\% 33,3$ 'ünde yarım saat, $\% 46,7$ 'sinde bir saat, \%20'sinde ise iki saat olarak belirtilmiştir. Akyol (2008)'un yaptığ 1 çalışmada hastaların daha kısa süre beklediği görülmüştür. Hastaların \%57,5'inin ağr1 başladıktan sonra ağrı tedavisi için 10 dakikadan az, \%8,3'ünün 11-20 dakika aras1 beklediği saptanmıştır. A ğrı bildiren hastaya en kısa süre içinde analjezik uygulanması gereklidir. Hatta ağrı başlamadan önce analjezik uygulanmasının hastanın ağrısız bir dönem geçirmesine faydalı olacağı önerilmektedir. ${ }^{3}$ Çalışmamızda hastaların bekleme süresi ile memnuniyet arasında bir fark bulunmadı fakat literatür incelendiğinde; Stomberg ve Oman (2006)'nın yaptıkları çalışmada hastaların çoğunluğunun, ağrı tedavisi için 15 dakikadan daha kısa süre bekledikleri belirtilmiştir. Yine aynı çalışma sonucunda, ağrı tedavisi ne kadar erken yapilırsa tedavi memnuniyetinin o kadar $\operatorname{arttı}_{\mathrm{g}} 1$ belirtilmiştir. ${ }^{16}$

Hastaların \%26,7'sine genel anestezi, $\% 31,7$ 'sine spinal anestezi, \%41,7'sine ise kombine anestezi yöntemi uygulandığ görüldü. Uygulanan anestezi yöntemine göre ağrı puanının değişmediği belirlenmiş olup
Erdem ve ark. (2011)'nın yaptığı çalışmada da spinal anestezi uygulanan hastaların ağrı düzeyi genel anestezi uygulananlardan düşük bulunmuştur. ${ }^{25}$ Ortopedik cerrahide spinal anestezinin genel anesteziye tercih edildiğini gösteren bazı çalışmalar mevcuttur. Çalışmamızda ağrı düzeyinde fark yaratmamakla birlikte anestezi yönteminin yürümede engellenme puanlarında fark yarattığ1 görülmüştür. Genel anestezi alan hastaların yürüme aktivitesinin, spinal anestezi ile ameliyat olanlara göre daha fazla etkilendiği bulundu. Genel anestezi alanların yürüme engellenme puan ortalaması $4 \pm 1,89$, spinal anestezi alanların yürüme engellenme puan ortalaması $3,26 \pm 2$ olup aradaki fark anlamli bulundu ( $\mathrm{p}=0,017)$.

Ameliyat sonrasinda yapılan nonfarmakolojik uygulamalar incelendiğinde hastaların \%23,3'üne elevasyon ve soğuk uygulama yapıldı̆̆ 1 , \%73,3'üne elevasyon, soğuk uygulama ve egzersiz yapıldığı belirlendi. Yıldırım ve Şendir'in çalışmasında hemşirelerin çoğunun $(\% 97,2)$ postoperatif ağrı yönetiminde nonfarmakolojik yöntemleri kullandığı, nonfarmakolojik girişimlerden çoğunlukla $(\% 47,2)$ soğuk uygulama, elevasyon ve masajı birlikte uyguladıkları saptanmıştır. ${ }^{26}$ Nonfarmakolojik yöntemlerin yoğun şekilde kullanılması, ortopedi kliniklerinde elevasyon ve soğuk uygulamanın hekim istemi ile uygulanmasina bağlı olarak yapıldığını düşündürmektedir. Literatürde etkin ağrı yönetimi için ilaç ve ilaç dışı yöntemlerin birlikte kullanılmasının yararlı olacağı bildirilmektedir. ${ }^{27}$ Hemşirelerin yapabileceği ilaç diş1 uygulamalardan biri de eğitimdir. Ameliyat öncesi eğitim verilmesi, ağrı yönetiminde etkilidir. Eğitim hastaların bilgilenmesini sağlamakla birlikte ağrıya yönelik pozitif tutum gelişimini sağlar. $\mathrm{Bu}$ şekilde hasta ameliyat sonrası ağrı hakkında gerçekçi beklentilere sahip olabilir ve anksiyeteyi azaltarak ağrının etkili yönetimi sağlanır ve hasta memnuniyeti artar. ${ }^{28,29}$

\section{SONUÇ VE ÖNERILER}

Sonuç olarak araştırmamızda diz protezi uygulanan erkek hastaların görüşme sırasındaki ağrı düzeyinin kadınlardan daha yüksek olduğu, ağrı nedeniyle hastaların en 
çok yürüme, genel aktivite ve emosyonel durumunun etkilendiği, genel anestezi alanlarda yürümenin spinal anestezi alanlara göre daha fazla etkilendiği, hemşirelerin ağrı gidermek için ilaç dışı yöntemlerden en s1k elevasyon, soğuk uygulama ve egzersiz uyguladığı, düzenli analjezik alma alışkanlığı olanlar hastalarda ameliyat sonrası ağrı düzeyinin daha yüksek olduğu saptandı. Hastaların memnuniyet puanı ortalamanın üzerinde bulundu, bağımsız değişkenlerin memnuniyeti etkilemediği belirlendi. En hafif ağr1 düzeyinin memnuniyeti etkilediği, ağr1 düzeyi azaldıkça memnuniyetin $\operatorname{arttığı~}$ görüldü.

Hastaların ameliyat öncesinde ağr1 konusunda bilgilendirilmesi, bakım planlamasında bireysel farklılıkların dikkate alınması, ağrı yönetiminde ilaç dışı yöntemlere daha fazla yer verilmesi ve ilaçların zamanında uygulanması önerilebilir. Farmakolojik olmayan yöntemlerin, psikolojik desteğin ve ağrı eğitiminin ameliyat sonrası ağrıyı azaltmada etkisini araştırmaya yönelik çalışmalar yapılması önerilebilir.
1. Bilge, A, Ulusoy, R.G, Üstebay, S. ve Öztürk, Ö. (2018) "Osteoartrit". Kafkas Journal Medical Science, 8 (Ek-1), 133142. doi: $10.5505 / \mathrm{kjms} .2016 .82653$

2. Yildırım, A. (2013). Total Diz Protezi Ameliyatı Olan Hastalarda Ameliyat Sonrası Ağrının Tanılanması ve Ağn Yönetimi. Yüksek Lisans Tezi, İstanbul Üniversitesi, Sağlık Blimleri Enstitüsü, İstanbul.

3. Akyol, Ö. (2008). Diz Protezi Uygulanan Hastalarda Ağr Prevelans1, Özellikleri, Etkileyen Etmenler ve Ağr Yönetiminden Memnuniyetin İncelenmesi. Yüksek Lisan Tezi, Dokuz Eylül Üniversitesi Sağlık Bilimleri Enstitüsü, Izmir.

4. Mac Lellan, K. (2004). "Postoperative Pain: Strategy for İmproving Patient Experiences". Journal of Advanced Nursing, 46 (2), 179-185

5. Bell, L. and Duffy, A. (2009). "Pain Assessment And Management İn Surgical Nursing". British Journal of Nursing, 18 (3), 153-156

6. Bozkurt, M, Yılmazlar, A. ve Bilgen, Ö.F. (2009). "Total Diz Artroplastisi Sonrası İntravenöz Ve Epidural Hasta Kontrollü Analjezi Tekniklerinin Ameliyat Sonrası Ağrı ve Diz Rehabilitasyonu Üzerine Etkilerinin Karşılaştırılması". Eklem Hastalık Cerrahisi, 20(2), 64-70.

7. Gillaspie, M. (2010). "Better Pain Management After Total Joint Replacement Surgery”. Orthopaedic Nursing, 29 (1), 20 25

8. Büyükyılmaz, F. ve Aștı T. (2009). "Ameliyat Sonrası Ağrıda Hemșirelik Bakımı". Atatürk Üniversitesi Hemșirelik Yüksekokulu Dergisi, 12(2);84-93.

9. Akyol, Ö, Karayurt, Ö. and Salmond, S. (2009). "Experiences of Pain and Satisfaction With Pain Management in Patients Undergoing Total Knee Replacement”. Orthopaedic Nursing, 28(2); 79-85.

10. Dahlen, L, Zimmerman, L. and Barron, C. (2006). "Pain Perception And İts Relation To Functional Status Post Total Knee Arthroplasty: a pilot study". Orthopaedic Nursing, 25(4), 264-269.

11. Dicle, A, Karayurt, Ö. and Dirimese, E. (2009). "Validation of the Turkish Version of the Brief Pain Inventory in Surgery patients". Pain Management Nursing, 10(2), 107-113. doi:10.1016/j.pmn.2008.08.002

12. Eti Aslan, F, Aygın, D. ve Sarıyıldız, D. (2007). "The
Satisfaction Level of Patients With Trauma On Pain Management”. Turkiye Klinikleri J Med Sci , 27, 687-94.

13. Eti Aslan, F, Kula Şahin, S, Seçginli, S. ve Bülbüloğlu, S (2018). "Hastaların, Ameliyat Sonrası Ağrı Yönetimine Ilisskin Hemşirelik Uygulamalarından Memnuniyet Düzeyleri: Bir Sistematik Derleme". Ağrı, 30(3), 105-115. doi: 10.5505/agri.2018.96720

14. Turhan Damar, H. ve Bilik, Ö. (2018). "Artroplasti Ameliyatı Olan Yaşlı Hastaların Ağrı Düzeyi ve Etkileyen Faktörler". Geriatrik Bilimler Dergisi / Journal of Geriatric Science, 1(3), 104-112.

15. Illgen, RL, Pellino, T.A, Gordon D.B, Butts, S. and Heiner, J.P. (2006). "Prospective Analysis of a Novel Long-Acting Oral Opioid Analgesic Regimen For Pain Control After Total Hip and Knee Arthroplasty". The Journal of Arthroplasty, 21 (6), 814-820. doi: 10.1016/j.arth.2005.10.011

16. Stomberg, M.W. and Oman, U.B. (2006). "Patients Undergoing Total Hip Arthroplasty: Perioperative Pain Experience" Journal of Clinical Nursing, 15, 451-458. doi: 10.1111/j.13652702.2006.01363.x

17. Berges, I.M, Ottenbacher, K.J, Smith, P.M, Smith, D. and Ostir, G.V. (2006). "Perceived Pain and Satisfaction With Medical Rehabilitation After Hospital Discharge", Clinic Rehabilitation, 20(8);724-730. doi $10.1191 / 0269215506$ cre 1006 oa.

18. Cremeans-Smith, J.K, Millington, K, Sledjeski, E, Green, K. and Delahanty, D.L. (2006). "Sleep Disruptions Mediate The Relationship Beteen Early Postoperative Pain and Later Functioning Following Total Knee Replacement Surgery". Journal of Behavioral Medicine, 29 (2), 215-222, doi: 10.1007/s10865-005-9045-0

19. Nikolajsen, L, Brandsborg, B. and Lucth, U. (2006). "Chronic Pain Following Total Hip Artroplasty: A Nationwide Questionnaire Study". Acta Anesthesiol Scand, 50, 495-500. doi: 10.1111/j.1399-6576.2006.00976.x.

20. Karayurt, Ö. (1998). “Ameliyat Öncesi Uygulanan Farkl Eğitim Programlarının Hastaların Anksiyete ve Ağrı Düzeylerine Etkisi”, Cumhuriyet Üniversitesi Hemșirelik Yüksekokulu Dergisi, 2 (1), 20-26.

21. Altındağ, Ö, Sırmatel, Ö. ve Tabur, H. (2006). "Diz Osteoartriti Olan Hastalarda Demografik Ozellikler ve Klinik parametrelerle İlişkisi”, Harran Üniversitesi Tıp Fakültesi Dergisi, 3 (2), 62-66.

22. Mutlu, A.E. (2016). Diz Osteoartritinde Yüksek Yoğunluklu 
Lazer Tedavisi (Hilt) ile Ultrason ve Kisa Dalga Diatermi Tedavisinin Ağrı ve Fonksiyonellik Üzerine Etkilerinin Karşılaştırılması. Uzmanlık Tezi, Abant İzzet Baysal Üniversitesi Tip Fakültesi Fiziksel Tip ve Rehabilitasyon Anabilim Dal1, Bolu.

23. Rahman, M.H. and Beattie, J. (2005). "Managing Postoperative Pain". The Pharmaceatual Journal, 275, 145-148.

24. Dikmen, Y.D. (2013). Ağrı ve Yönetimi. İn: Aștı TA, Karadağ A. (Ed). Hemşirelik Esasları. İstanbul: Akademi Basın Yayıncilik.

25. Erdem, D, Ugiş, C, Albayrak, M.D, Akan, B, Aksoy, E. ve Göğüss, N. (2011). "Perianal Bölge Ameliyatı Yapılacak Hastalarda Uygulanan Anestezi Yöntemlerinin Preoperatif ve ameliyat sonrası Anksiyete ve Ağrı Düzeylerine Etkisi”, Bakırköy Tıp Dergisi, 7 (1), 11-16.

26. Yıldırm, A. ve Şendir, M. (2019). "Total Diz Protezi Ameliyatı Olan Hastalarda Postoperatif Ağrının Tanılanması ve Ağrı Yönetimi” Sağlık Bilimleri Üniversitesi Hemşirelik Dergisi / University of Health Sciences Journal of Nursing, 1 (3), 157164.

27. Pellino, T.A, Gordon, D.B, Engelke, Z.K, Busse K.L, Collins, M.A, Silver, C.E. and Norcross, N.J. (2005). "Use of Nonpharmacologic Interventions For Pain and Anxiety After Total Hip and Total Knee Arthroplasty." Orthopaedic Nursing, 24 (3), 182-190. doi: 10.1097/00006416-200505000-00005

28. Clifford, W. and Colwell, J.R. (2008). "Management of Pain After Total Knee Arthroplasy". Seminars in Arthroplasty, 19, 243.

29. Bell, L. and Duffy, A. (2009). "Pain Assessment and Management in Surgical Nursing. "British Journal of Nursing, $18(3), 153-156$. 